\title{
Macroeconomic Variables and Stock Market Returns in Sri Lanka
}

\author{
Saseela Balagobei \\ Senior Lecturer, Department of Financial Management \\ Faculty of Management Studies and Commerce \\ University of Jaffna
}

Received: Sep. 11, 2017 Accepted: Nov. 20, $2017 \quad$ Published: December 1, 2017

doi:10.5296/ajfa.v9i2.11832 URL: https://doi.org/10.5296/ajfa.v9i2.11832

\begin{abstract}
The stock market is one of the most energetic sectors that play an important role in contributing to the wealth of the economy. It plays a crucial role in the economic growth and development of an economy which would benefit industries, trade and commerce as a whole. The aim of this study is to investigate the impact of macroeconomic variables on stock market returns in Sri Lanka. Dependent variable of this study is stock market return measured by All Share Price Index (ASPI) and All Share Total Return Index (ASTRI) and independent variables are macroeconomic variables, such as Interest Rate (IR), Inflation Rate (INF), Exchange Rate (ER), Factory Industry Production Index (FIPI) and money supply (MS). The study targets all the companies listed and active in Colombo Stock Exchange (CSE) from 2006 to 2015. For analysis, secondary data was collected from annual reports of Central bank of Sri Lanka, Colombo Stock Exchange, Securities and Exchange Commission and Department of Census and Statistics. The results of the study reveal that the stock market returns is influenced by macroeconomic variables except money supply in Sri Lanka. Interest rate and factory industry production have negative influence on stock market return in Colombo Stock exchange while inflation rate and exchange rate have positive influence on stock market return. The findings of the study may be useful to public and economy especially stock market investors to focus the macroeconomic variables for making their effective decisions in order to enhance their stock market returns.
\end{abstract}

Keywords: Macroeconomic variables, Stock market return, All share price index and All share total return index. 


\section{Introduction}

Stock market has a paramount importance in an economy. Although most of the growing economies are endowed with growing stock markets, due to prevailed unfavorable economic and political condition in Sri Lanka, Colombo Stock Exchange (CSE) remained underdeveloped during the pre-war period. However, due to considerable economic growth and peaceful political environment, CSE reported a robust growth in the post-war period. Nevertheless, despite the impressive economic environment emerged, the stock market growth was not sustained after 2012. Therefore, the constraints for stock market development remain unclear (Kulathunga, 2015).

The Colombo stock exchange (CSE) operates as the only share market in the economy and is responsible for providing a transparent and regulated environment where both institutional and individual investors can operate in the capital market. The study intends to investigate the impact of macroeconomic variables on stock market returns in Colombo Stock Exchange, Sri Lanka. Stock market is somehow abstract for the mechanism that enables the trading of company stock. It is also used to describe the totality of all stocks, especially within a country. The stock market is the market where common stock representing ownership in a company, are traded (Mishkin and Eakins, 2011). It plays an important role in national economies, as they are considered to be very helpful in channeling and diversifying the domestic savings and foreign capital into productive investment, fostering capital formation and sustaining economic growth and development (Lakshmi and Tuwajri, 2014).

The association between macroeconomic variables and stock market returns has been extensively studied and documented in developed capital markets such as USA, Japan, Australia, Canada and European countries. Notable among them is one by Chen, Richard Roll and Ross (1986) on the US stock market, which set the tone for a series of recent studies within the Arbitrage Pricing Theory (APT) framework. According to Fama (1981), macroeconomic variable such as industrial production index is positively related with stock market performance. When industrial production index increases, the stock returns also increase. The industrial production and interest rate in Germany have a positive relationship with other European stock market returns as well such as United Kingdom, France and Italy (Cheung \& Ng 1998, Nasseh \& Strauss 2000, Mukherjee \& Naka 1995, McMillan 2001 and Chaudhuri \& Smiles 2004).

Stock Market Returns are the returns that the investors generate out of the stock market. These returns can be in the form of profit through trading or in the form of dividends given by the company to its shareholders from time-to-time. Macroeconomic variables show the overall strength or weakness of the economy. The most important macroeconomic variables are Gross domestic product (GDP), inflation, money supply, interest rate, exchange rate, unemployment rate, foreign direct investment and index of industrial production (Alam \& Rashid, 2014).

It is a matter of great interest for academician, researchers, investors, regulators and government bodies to identify impact of macroeconomic variables on the stock market. Stock 
markets being a leading indicator of an economy reflect the level of economic activities in the country (Menike, 2006).

In related to the literature there were many studies have been investigated the relationship between macroeconomic variables and stock market returns in developed countries, for instance, Chen et al., (1986) who examined US stock market and it is obvious that there is a shortage of literature concerning on emerging stock markets, but it is particularly lacking in regards to the Sri Lankan market. However, there is only a little number of studies in emerging Sri Lankan Stock Market such as of Samarakoon, (1996, 1998), Nimal, (1997), Premawardhana (1997), Samarakoon et al. (2000). For example, Samarakoon (1996) reported a positive relationship between stock market returns and inflation. Based on the best of researcher's knowledge still on Sri Lankan markets, of the reviewed literature, no specific one has attempted to examine the impact of macroeconomic variables such as interest rate, inflation rate, exchange rate, factory industry production index and money supply on stock market returns.

Knowing how the stock market returns affect as a response to macroeconomic changes is essential for those who are looking for returns on their investments and policy makers. Frequently, research in this area has found statistical proof to support the theory that macroeconomic variables impact the stock market returns, however there are also studies that found no causal relationship between some of the variables such as Factory Industry Production Index, business surveys of manufacturing orders, short and long term interest rates as well as foreign stock prices, short-term interest rates and production (Nasseh and Strauss, 2000; Tangjitprom, 2012). A common feature of these studies is that they focus on the whole market and examine the aggregate market of countries (Rapach, Wohar and Rangvid, 2005; Pierdzioch, Döpke and Hartmann, 2008). They assume that the firms are homogenous. To address this issue this study was undertaken to explore the answer to the following research question: To what extent macroeconomic variables impact on stock market returns? The objective of this study is to investigate the impact of macroeconomic variables on stock market returns in Sri Lanka during the period of 2006 to 2015.

\section{Literature Review}

This section reviews literature on the concepts relevant to the study. The effect of macroeconomic variables on stock market return has been documented in developing countries as well as developed countries.

Using data from 1976 to 1993 on 41 countries including both developed and developing, Levine and Zervos (1996) examined the relationship between economic growth and stock market development. They found a strong positive association between the stock market development and long-run economic growth after controlling for the initial level of per capita GDP, initial level of investment in human capital, political instability and measures of fiscal and monetary policies as well as exchange rate policy. Atje and Jovanovic (1993) found strong evidence to support the view that stock market development leads to economic growth. Johansen and Juselus (1999) investigated the long run relationship between the Jordanian stock prices and selected macroeconomic variables by using cointegration analysis and 
monthly time series data for the period of January 1987 to December 2000.The study reveals that macroeconomic variables were reflected in stock prices in the Jordanian capital market.

Gunasekarage, Pisedtasalasai and Power (2004) examined the influence of macroeconomic variables on stock market equity values in Sri Lanka, using the Colombo All Share price index to represent the stock market and (1) the money supply, (2) the treasury bill rate (as a measure of interest rates), (3) the consumer price index (as a measure of inflation), and (4) the exchange rate as macroeconomic variables. With monthly data for the 17-year period from January 1985 to December 2001 and using unit root tests, cointegration, and VECM, they examined both long-run and short-run relationships between the stock market index and the economic variables. The VECM analysis provides support for the argument that the lagged values of macroeconomic variables such as the consumer price index, the money supply and the Treasury bill rate have a significant influence on the stock market.

Patra and Poshakwale (2006) examined the short-run dynamic adjustments and the long-run equilibrium relationships between selected macroeconomic variables, trading volume and stock returns in the Greek stock market during the period of 1990 to 1999. They reach results showing that short run and long run equilibrium relationship exists between inflation, money supply and trading volume and the stock prices in the Athens stock exchange. No short run or long run equilibrium relationship is found between the exchange rates and stock prices.

Abugri (2006) performed a study to determine whether selected macroeconomic indicators like exchange rates, interest rates, industrial production and money supply in four Latin American countries significantly explain market returns. His research results indicated that the global factors are consistently significant in explaining returns in all the markets. The country macroeconomic variables are found to impact the markets at varying significance and magnitudes.

According to Chen et al. (1986) economic variables have a systematic consequence on stock market returns because economic forces affect the discount rates, the ability of firms to generate cash flows and future dividend payments. It is through this mechanism that macroeconomic variables become part of risk factors in equity markets. They (1986) analyzed the macroeconomic variables and stock returns and found a strong relationship between stock returns and macroeconomic variables of short term and long term interest rates, expected and unexpected inflation rate and industrial production growth.

Menike (2006) studied impact of macroeconomic variables on stock price in emerging Sri Lankan Stock Market using monthly data for the period from September 1991 to December 2002. The study held that inflation rate, Treasury bill rate and exchange rate react mainly negatively to stock prices. However, lagged money supply variables were held not to have a strong prediction of the movements of stock prices.

Samarakoon (1998) investigated the relationship between stock returns and inflation in Sri Lanka with a view to providing empirical evidence on the generalized Fisher Hypothesis which states that nominal stock returns are positively related to expected inflation in a one-to-one correspondence. The results indicate that both lagged inflation and expected 
inflation are significantly positively related to stock returns in a manner predicted by the Fisher Hypothesis suggesting that stocks in Sri Lanka. Rahman (2009) believes that in long term, foreign exchange reserve and industrial production positively affect on stock market, while interest rate and exchange rate have the reverse influence on Malaysian stock market.

Maysami (2004) using the same analysis found that Singapore stock market has a cointergrating relationship with changes in the short and long-term interest rates, industrial production, price levels, exchange rate and money supply. Imbrahim and Yusoff (2001) stated that Malaysian stock market is strongly affected by domestic macroeconomic factors, in which money supply is one of the strongest influences. Money supply has short-term positive effect on this stock market but negatively effect in long term, while industrial production and inflation rate have positively effect on the market.

For the case of Malaysia, Ibrahim and Yusoff (2001) find a negative relationship between stock prices and money supply in the long-run but the analysis actually between the stock prices (KLCI) and macroeconomic variables which are real output as a measure of industrial production (IP), money supply (M2), price level as a measure of consumer price index (CPI) and exchange rate. KLCI is positively related to CPI and negatively related to M2. The positive association between KLCI and CPI seems to support the view that the stock prices are a good hedge against inflation. Mukherjee and Naka (1995) applied Johansen's VECM method and found a cointergrating relationship between Japan stock market and inflation, exchange rate, money supply, real economic activity, long-term government bond rate, and call money rate.

Azman-Saini, Habibullah, Law and Dayang-Afizzah (2006) in their study by using Granger non-causality found that Malaysian stock prices are led by the exchange rate during the crisis period. During the crisis period, the Malaysian Ringgit depreciated against US dollar and it significantly influences the Malaysian stock prices.

This study considers a longer time span (2006-2015) and more observations and also considers the impact of macroeconomic variables (Interest rate, Inflation, Exchange rate, Factory Industry Production Index and money supply) on the changes in the stock market return of Colombo Stock Exchange

Based on the above literature review, the following testable hypotheses are developed:

$\mathrm{H}_{1}$ : Interest rate significantly influences on stock market returns.

$\mathrm{H}_{2}$ : Inflation rate significantly influences on stock market returns.

$\mathrm{H}_{3}$ : Exchange rate significantly influences on stock market returns.

$\mathrm{H}_{4}$ : Factory Industry Production Index significantly influences on stock market returns.

$\mathrm{H}_{5}$ : Money supply significantly influences on stock market returns.

\section{Methodology}

This section focuses on the research process, kind of tools and procedures to be used. This study tends to investigate the impact of macroeconomic variables on stock market return in 
Sri Lanka. The Colombo stock exchange (CSE) is the only one share market in Sri Lanka and this study focuses on the stock market as wholly. The researcher mainly focuses on secondary data which is collected from annual reports of central bank of Sri Lanka, CSE and Department of Census and Statistics, and academic journals for the period of 2006-2015. Further All share price index (ASPI) and All share total return index (ASTRI) represent the total 295 listed companies' performance in Sri Lanka.

Five variables have been considered as macro economic variables: interest rate (364 days treasury bill weighted annual average yield rate); Inflation rate (Changes in Colombo consumers' price index); Exchange rate (Sri Lankan rupee to the US dollar has been used); Factory industry Production (Index of factory industry Production); and Money supply (Broad money supply (M2b)) whereas All share price index (The base year is 1985, and the base value of the index is 100) and All share total return index (The ASPI computed on total returns is known as ASTRI) are used as the proxies for stock market return.

A multiple linear regression model attempts to investigate the influence of selected macro economic variables on stock market return.

$$
\begin{aligned}
& \text { ASPI }=\beta_{0}+\beta_{1} \mathrm{IR}+\beta_{2} \mathrm{INF}+\beta_{3} \mathrm{ER}+\beta_{4} \mathrm{FIPI}+\beta_{5} \mathrm{MS}+\varepsilon \\
& \text { ASTRI }=\beta_{0}+\beta_{1} \mathrm{IR}+\beta_{2} \mathrm{INF}+\beta_{3} \mathrm{ER}+\beta_{4} \mathrm{FIPI}+\beta_{5} \mathrm{MS}+\varepsilon
\end{aligned}
$$

Where:

$\beta 1, \beta 2 \beta 3, \beta 4, \beta 5-$ Regression coefficient

IR - Interest rate

INF - Inflation

ER - Exchange rate

FIPI - Factory Industry Production Index

MS -Money supply

$\varepsilon \quad-$ Error term

\section{Data Analysis}

\section{Descriptive Analysis}

Table 1 represents the descriptive statistics of macroeconomic variables and stock market return measured by ASPI and ASTRI in Sri Lanka from 2006 to 2015. 
Table 1. Descriptive Statistics

\begin{tabular}{lrrrr}
\hline & Minimum & Maximum & Mean & $\begin{array}{c}\text { Std. } \\
\text { Deviation }\end{array}$ \\
\hline Interest rate & 6.60 & 18.89 & 11.07 & 4.09 \\
Inflation rate & 0.90 & 22.60 & 8.35 & 6.46 \\
Exchange rate & 103.96 & 135.94 & 118.52 & 11.25 \\
Factory industry production index & 86.60 & 124.60 & 104.76 & 13.00 \\
Money Supply & 1204.60 & 4565.90 & 2530.95 & 1138.26 \\
ASPI & 1503.00 & 7298.95 & 4861.15 & 2103.65 \\
ASTRI & 1783.60 & 9579.20 & 6015.34 & 2829.73 \\
\hline
\end{tabular}

The table 01 summarizes the descriptive statistics for the variables employed in the study. This shows that the average interest rate of $11.07 \%$ with a standard deviation of 4.09 and has a wide range from 6.60 to 18.89 . This table also shows that the average inflation rate is $8.35 \%$ with a standard deviation of 6.46 and has a range from 0.90 to 22.60 . Money supply has the average of Rs.2530.95 billion while minimum value of Rs.1204.60 billion and maximum of Rs.4565.90 billion. The average annual ASPI and ASTRI are 4861.15 and 6015.34 respectively. There is a highest standard deviation of stock market returns and lower standard deviation of interest rate.

\subsection{Correlation Analysis}

This study employs a correlation analysis to discover the association and direction of the variables, mainly macroeconomic variables and stock market return. 
Table 2. Correlation Matrix

\begin{tabular}{lllllllll}
\hline & & IR & INF & ER & FIPI & MS & ASPI & ASTRI \\
\hline IR & Pearson Correlation & 1 &. & & & & & \\
& Sig. (2-tailed) & & & & & & & \\
INF & Pearson Correlation & $.873^{* *}$ & 1 & & & & & \\
& Sig. (2-tailed) & .001 & & & & & & \\
ER & Pearson Correlation & -.497 & -.612 & 1 & & & \\
& Sig. (2-tailed) & .144 & .060 & & & & \\
\multirow{2}{*}{ FIPI } & Pearson Correlation & $-.745^{*}$ & -.559 & .534 & 1 & & & \\
& Sig. (2-tailed) & .013 & .093 & .112 & & & & \\
\multirow{2}{*}{ MS } & Pearson Correlation & $-.658^{*}$ & $-.649^{*}$ & $.950^{* *}$ & $.662^{*}$ & 1 & & \\
& Sig. (2-tailed) & .039 & .042 & .000 & .037 & & & \\
\multirow{2}{*}{ ASPI } & Pearson Correlation & $-.886^{* *}$ & $-.792^{* *}$ & $.720^{*}$ & .617 & $.817^{* *}$ & 1 & \\
& Sig. (2-tailed) & .001 & .006 & .019 & .057 & .004 & & \\
\multirow{2}{*}{ ASTRI } & Pearson Correlation & $-.870^{* *}$ & $-.782^{* *}$ & $.773^{* *}$ & $.639^{*}$ & $.866^{* *}$ & $.995^{* *}$ & 1 \\
& Sig. (2-tailed) & .001 & .008 & .009 & .047 & .001 & .000 & \\
\end{tabular}

**Correlation is significant at the 0.01 level (2tailed).

* Correlation is significant at the 0.05 level (2-tailed).

According to the table 02 the value of correlation between interest rate and ASPI is $-0.886^{* *}$ which is significant at 0.01 levels; indicates that there is strong negative association between IR and ASPI, also strong negative relationship exists between interest rate and ASTRI at the 0.01 significant levels since the value of correlation between interest rate and ASTRI is $-0.87 * *$. As can be seen in table 02 , the value of correlation between inflation and ASPI is $-0.792 * *$ which is significant negative relationship between inflation and ASPI at 0.01 levels. The value of correlation between inflation and ASTRI is $-0.782 * *$ indicates that there is significant negative relationship between inflation and ASTRI at 0.01 levels.

The correlation between exchange rate and ASPI is $0.720^{* *}$ which represents a positive significant relationship between ER and ASPI at 0.05 significant levels. The value of correlation between exchange rate and ASTRI is $0.773^{* *}$ which is significant at 0.01 levels represents the positive relationship between ER and ASTRI. Further there is insignificant relationship between factory industry production index and ASPI at 0.05 significant levels. But there is significant positive relationship between FIPI and ASTRI at 0.05 significant levels. Further the correlation between money supply and ASPI is $0.817^{* *}$ which indicates a strong positive relationship between money supply and ASPI at the 0.01 significant level and also there is strong positive relationship between money supply and ASTRI at 0.01 significant level. 


\section{Regression Analysis}

In order to examine the impact of macroeconomic variables on stock market return, multiple regression analysis is performed in this study. Results of the multiple regression analysis are presented in the table 03 and table 04.

Table 3. Multiple regression Analysis for ASPI

\begin{tabular}{|c|c|c|c|c|}
\hline Variables & Beta & Std. Error & t value & Sig. \\
\hline (Constant) & -6345.741 & 7114.305 & -.892 & .423 \\
\hline IR & -963.513 & 183.785 & -5.243 & .006 \\
\hline INF & 287.214 & 90.032 & 3.190 & .033 \\
\hline ER & 264.991 & 88.600 & 2.991 & .040 \\
\hline FIPI & -74.230 & 21.887 & -3.391 & .027 \\
\hline MS & -1.759 & .984 & -1.788 & .148 \\
\hline$R^{2}=.977$ & $R^{2}=$ & .948 & & $F=33.937$ \\
\hline$p(F$ statistic $)=0.002$ & & & & \\
\hline
\end{tabular}

Dependent Variable: ASPI

According to the table 03 , coefficient of determination for macroeconomic variables $\left(\mathrm{R}^{2}\right)$ is 0.977 which denotes that $97.7 \%$ of the observed variability in ASPI can be explained by the differences in the variables such as IR, INF, ER, FIPI and MS The remaining $2.3 \%$ of the variances is related to the other variables which are not depicted in this model. An analysis of variance (ANOVA) indicated that $F=33.937, p<0.05$, that the model is significant. It means that the regression results are acceptable for this analysis.

Among the all five macroeconomic variables considered in the analysis, only four macroeconomic variables have a significant impact on ASPI which are interest rate, inflation rate, exchange rate and Factory Industry Production index. Interest rate significantly negatively influences on ASPI $(B=-963.513, p<0.05)$, similar pattern is observed in factory industry production index that has significant negative impact on ASPI $(B=-74.230, p<0.05)$. Further inflation rate significantly positively influences on ASPI $(B=287.214, p<0.05)$, and exchange rate has a significant positive impact on ASPI $(B=264.991, p<0.05)$. The coefficient of money supply shows that money supply has no significant impact on ASPI. 
Table 4. Regression Analysis for All share price index

\begin{tabular}{lrrrr}
\hline \multicolumn{1}{c}{ Variables } & \multicolumn{1}{c}{ Beta } & Std. Error & t value & Sig. \\
\hline Constant $)$ & -8647.289 & 7361.440 & -1.175 & .305 \\
IR & -1159.700 & 190.169 & -6.098 & .004 \\
INF & 356.587 & 93.159 & 3.828 & .019 \\
ER & 320.023 & 91.678 & 3.491 & .025 \\
FIPI & -89.050 & 22.648 & -3.932 & .017 \\
MS & -1.725 & 1.018 & -1.694 & .166 \\
\hline$R^{2}=0.986$ & Adj. $R^{2}=.969$ & $F=57.904$ & $p($ F statistic $)=0.001$ \\
\hline
\end{tabular}

Dependent Variable: ASTRI

According to the table 04 , coefficient of determination for macroeconomic variables $\left(\mathrm{R}^{2}\right)$ is 0.986 which denotes that $98.6 \%$ of the observed variability in ASTRI can be explained by the differences in the variables such as IR, INF, ER, FIPI and MS The remaining $1.4 \%$ of the variances is related to the other variables which are not depicted in this model. An analysis of variance (ANOVA) indicated that $\mathrm{F}=57.904, \mathrm{p}<0.05$, that the model is significant. It means that the regression results are acceptable for this analysis.

Only four macroeconomic variables have a significant impact on ASTRI which are interest rate, inflation rate, exchange rate and factory industry production index. Interest rate significantly negatively influences on ASTRI $(B=-1159.700, p<0.05)$, similar pattern is observed in factory industry production index that has significant negative impact on ASTRI $(B=-89.050, p<0.05)$. Further inflation rate significantly positively influences on ASTRI $(B=$ $356.587, \mathrm{p}<0.05)$, and exchange rate has a significant positive impact on ASTRI $(B=320.023$, $\mathrm{p}<0.05$ ). The coefficient of money supply shows that money supply has no significant impact on ASTRI.

By using the multiple regression analysis the hypotheses are examined in this study. Hypothesis $\left(\mathrm{H}_{1}\right)$ stated that interest rate significantly influences on stock market returns. According to the table 03 and table 04 , there is a significant negative impact of interest rate on stock market return measured by ASPI and ASTRI ( $\mathrm{p}=0.006<0.05, \mathrm{p}=0.004$ respectively), as a result $\mathrm{H}_{1}$ is supported. The result is consistence with the findings of previous researches such as Johansen and Juselus (1999); Abugri (2006); Chen et al. (1986) and Menike (2006). Hypothesis $\left(\mathrm{H}_{2}\right)$ stated that Inflation rate significantly influences on stock market returns measured by ASPI and ASTRI. Since the p-values of $t$ test for inflation rate are $0.033<0.05$ and $0.019<0.05$, which illustrated that there is a significant positive impact of inflation rate on stock market returns, as a result $\mathrm{H}_{2}$ is supported. 
Hypothesis $\left(\mathrm{H}_{3}\right)$ stated that exchange rate significantly influences on stock market returns. Since the $p$-values of $t$ test for exchange rate are $0.04<0.05$ and $0.025<0.05$, which illustrated that there is a significant positive impact of exchange rate on stock market returns, as a result $\mathrm{H}_{3}$ is supported.

Hypothesis $\left(\mathrm{H}_{4}\right)$ stated that factory Industry Production Index significantly influences on stock market returns. Since the p-values of t test for factory Industry Production Index are $0.027<0.05$ and $0.017<0.05$, which illustrated that there is a significant negative impact of factory Industry Production Index on stock market returns, as a result $\mathrm{H}_{4}$ is supported. Hypothesis $\left(\mathrm{H}_{5}\right)$ stated that money supply significantly influences on stock market returns. Since the p-values of $t$ test for money supply are $0.148>0.05$ and $0.166>0.05$, which illustrated that there is no significant impact of money supply on stock market returns, as a result $\mathrm{H}_{5}$ is not supported.

\section{Conclusion}

Having understood the importance of macroeconomic variables and stock market return to the country, the present study has been carried out to assess the impact of macroeconomic variables on stock market return in Sri Lanka. There is a whole listed companies considered in this study. Results of the study reveal that among the five macroeconomic variables, only interest rate and factory industry production have a significant negative influence on stock market return in Colombo Stock exchange. Further inflation rate and exchange rate have a significant positive influence on stock market return while there is no significant impact of money supply on stock market return in Colombo Stock exchange.

Therefore the stock market returns is influenced by macroeconomic variables except money supply in Sri Lanka. So considering the macroeconomic variables, every investor should make good decisions regarding their investment and every firm should contribute to the overall stock market return in order to carry out their business successfully and to maintain the good investor relationship.

Interest rate is a crucial variable of stock market return in Sri Lanka. In this study, interest rate is found to have negative significant impact on stock market return. According to the findings, the stock returns react negatively to rising interest rates. Therefore, high interest rates influence the stock market returns and subsequently causing stock prices to fall. Whenever returns on government assets increase, investors are likely to change out of stocks and causing a decrease in stock prices. This can be explained through the behavior of the weighted average yield rates of 364 days Treasury bill. Inflation rate is one of the pivotal variables of stock market returns which have positive significant impact on stock market return. Investors should put more caution about inflation in the market. The Central Bank of Sri Lanka being the monetary authority in Sri Lanka need to constantly be reviewing the interest rate trends, inflation rates as well as the exchange rate by comparing them with the developed economies.

The finding of the study may be useful to public and economy especially stock market investors to focus the macroeconomic variables for making their effective decisions in order 
to enhance their stock market return. Other stakeholders such as policy maker, Central bank of Sri Lanka, economist, and stock market participants should be more awareness in the situation of Sri Lankan stock market trend and the significant impact of interest rate, inflation rate, exchange rate, FIPI and money supply on stock market return.

\section{References}

Abugri B.A. (2006). Empirical relationship between macroeconomic volatility and stock returns: Evidence from Latin American markets. International Review of Financial Analysis, $19,228-245$.

Alam, M., \& Uddin,G.S.(2009). Relationship between Interest Rate and Stock Price: Empirical Evidence from Developed and Developing Countries. International Journal of Business and Management, 3(4), 43-51. https://doi.org/10.5539/ijbm.v4n3p43

Atje, R., \& Jovanovic, B. (1993). Stock markets and development. European Economic Review, 37, 632-640. https://doi.org/10.1016/0014-2921(93)90053-D

Azman-Saini, W. N. W., Habibullah, M. S., Law, S. H., \& Dayang-Afizzah, A. M. (2006), Stock Prices, Exchange Rates and Causality in Malaysia: A Note. The ICFAI Journal of Financial Economics, 5, 7-13.

Chen, N.F., R. Roll, \& S.A. Ross, (1986). Economic forces and the stock market. Journal of Business, 59, 383-403. https://doi.org/10.1086/296344

Coleman, A. K., \& Tetty, K. F.A. (2008).Impact of Macroeconomic variables on Ghana stock exchange. Journal of Risk and Fiinance, 4, 365-378. https://doi.org/10.1108/15265940810895025

Gunasekarage, G., Pisedtasalasai, A. \& Power, D. M. (2004). Macroeconomic Influence on the Stock Market: Evidence from an Emerging Market in South Asia. Journal of Emerging Market Finance, 3(3), 285-304. https://doi.org/10.1177/097265270400300304

Ibrahim,M.H.(1999). Macroeconomic Variables and Stock Prices in Malaysia: An Empirical Analysis. Asian Economic Journal, 13(2), 219-231. https://doi.org/10.1111/1467-8381.00082

Ibrahim, M \& Yusoff. (1999). Macroeconomics Variables and Stock Price in Malaysia: an Empirical Analysis. Asian Economic Journal, 13(2), 219-231. https://doi.org/10.1111/1467-8381.00082

Kulathunga, K. (2015). Macroeconomic Factors and Stock Market Development: With Special Reference to Colombo Stock Exchange. International Journal of Scientific and Research Publications.

Johansen, S., \& Juselius, K. (1990). Maximum likelihood estimation and inference on cointegration with applications to the demand for money. Oxford Bulletin of Economics and Statistics, 52, 169-210. https://doi.org/10.1111/j.1468-0084.1990.mp52002003.x

Levine, R., \& Zervos, S. (1996a). Stock market development and long-run growth. The World Bank Economic Review, 2, 323-39. https://doi.org/10.1093/wber/10.2.323 


\section{Macrothink}

Maysami, R. C., Lee, C. H., \& Hamzah, M. A. (2004). Relationship between Macroeconomic Variables and Stock Market Indices: Cointegration Evidence from Stock Exchange of Singapore's All-S Sector Indices. Jurnal Pemgurusan, 24, 47-77.

Menike, L. M. C. S. (2006). The Effect of Macroeconomic Variables on Stock Prices in Emerging Sri Lankan Stock Market. Sabaragamuwa University Journal, 6(1), 50-67.

Mukherjee, T.K., \& A. Naka, (1995). Dynamic relations between macroeconomic variables and the Japanese stock market: An application of a vector error correction model. Journal of Financial Research, 18, 223-237. https://doi.org/10.1111/j.1475-6803.1995.tb00563.x

Patra T., \& Poshakwale S. (2006). Economic variables and stock market return; evidence from the Athens stock exchange. Applied Financial Economics, 6, 993-1006. https://doi.org/10.1080/09603100500426523

Rahman, A. A., Sidek, N.Z.M., \& Tafri, F. H. (2009).Macroeconomic Determinants of Malaysian Stock Market. African Journal of Business Management, 3(3), 95-106.

Samarakoon, L.P. (1996b). Stock market returns and inflation: Sri Lankan Evidence. Sri Lankan Journal of Management, 1, 293 - 311. 